\title{
PEMBUATAN ALAT PEMBELAH KAYU DAN PENYERUT BAMBU PADA KELOMPOK USAHA PENGRAJIN SANGKAR BURUNG DI DESA TOYOMARTO KECAMATAN SINGOSARI KABUPATEN MALANG
}

\author{
Faqih Rofii $^{1}{ }^{*}$ Fachrudin Hunaini $^{1}$, Ngudi Tjahjono ${ }^{1}$ \\ ${ }^{1}$ Fakultas Teknik, Universitas Widyagama Malang, Malang, Indonesia \\ *Penulis Korespodensi: faqih@widyagama.ac.id
}

\begin{abstract}
Abstrak
Meningkatnya jumlah penghobi burung, berdampak terhadap peningkatan permintaan sangkar burung. Salah satu tujuan dari kegiatan pengabdian masyarakat ini adalah untuk meningkatkan produktifitas kelompok usaha pembuatan sangkar burung yang berada di Desa Toyomarto, Singosari Malang. Permasalahan produksi yang dapat diidentifikasi adalah terbatasnya peralatan proses produksi yang digunakan, disebabkan masih manualnya peralatan kerja pada proses pembelahan kayu, pembelahan bambu menjadi jeruji dan penyerutan jeruji agar menjadi halus. Prioritas permasalahan yang diselesaikan adalah perancangan dan pembuatan meja pemotong dan pembelah kayu menggunakan penggerak motor listrik, perancangan dan pembuatan alat serut dan penghalus bambu untuk jeruji sangkar menggunakan penggerak motor listrik serta peningkatan kemampuan tenaga kerja dalam pengoperasian peralatan tersebut. Adapun metode pelaksanaannya adalah merancang, merealisasikan, menguji dan mendemonstrasikan alat, serta melatih dan mendampingi pemakaian alat. Hasil yang dicapai dari pembuatan alat pembelah kayu dan penghalus bambu ini adalah kayu yang dibelah lebih lurus dan halus, dapat mengatur ketebalan kayu yang dibelah, dan proses pembelahan dan penghalusan menjadi lebih cepat.
\end{abstract}

Kata kunci: Sangkar burung, Pembelah kayu, Penyerut bambu, Motor listrik

\begin{abstract}
The increasing number of bird hobbyists, has an impact on increasing demand for bird cages. One of the goals of this community service activity is to increase productivity of bird cage making business group in Toyomarto Village, Singosari Malang. Production issues that can be identified are the limited equipment used production process, caused still manual work equipment on the process of cleavage of wood, cleavage of bamboo into the bars and grate shrinkage to be smooth. The priority issues that are solved are the design and manufacture of wood cutting and splitting tables using electric motor propulsion, design and manufacture of cutting tools and bamboo polishes for cage bars using electric motors as well as increasing the ability of labor in the operation of the equipment. The method of implementation is to design, realize, test and demonstrate tools, and train and assist the use of tools. The results obtained from the manufacture of wooden and bamboo splitting tools are wood split more straight and smooth, can adjust the thickness of the split wood, and the process of splitting and refining becomes faster.
\end{abstract}

Keywords: Bird cages, Cleavage of wood, Cleavage of bamboo, Electrical Motor

\section{PENDAHULUAN}

Perkembangan jumlah penghobi burung di Indonesia saat ini tidak bisa diketahui secara pasti. Namun dapat dipastikan bahwa penghobinya semakin banyak dan masuk ke semua segmen masyarakat. Meningkatnya jumlah penghobi burung terlihat dari trafik kunjungan ke blog OmKicau.Com, yang setiap hari menunjukkan pertambahan orang yang berbeda, yang bisa dilihat dari alamat protokol internet (IP address) digunakan, juga dari alamat email serta jumlah pelanggan blog OmKicau.Com. Meningkatnya jumlah penghobi burung, tentu berdampak pada meningkatnya kebutuhan akan sangkar burung (Kicau, 2011). Salah satu bidang usaha kerajinan sangkar burung yang berkembang di Kabupaten Malang terdapat di Desa Toyomarto Kecamatan Singosari. Usaha ini telah dilakukan secara turun temurun oleh penduduk sekitar, sehingga daerah tersebut sudah menjadi basis usaha kerajinan sangkar burung yang menjadi rujukan bagi para pengusaha besar, maupun pengguna langsung didalam mencari produk sangkar burung. Pengrajin sangkar burung di daerah tersebut sudah ada dan berkembang sejak sekitar tahun dua ribuan, namun hanya sedikit pengrajin yang mengembangkan usaha 
ini, dikarenakan membutuhkan ketrampilan, keuletan, kreatifitas dan kemampuan seni yang tinggi.

Bahan baku utama pembuatan sangkar burung adalah bambu dan kayu kering. Di daerah mitra banyak terdapat kayu limbah pembuatan meubel. Warga di sekitar perusahaan pembuatan meubel, banyak menggunakan kayu limbah tersebut untuk digunakan sebagai bahan dasar berbagai macam pembuatan kerajinan bernilai komersil, yaitu : sangkar burung, mainan anak, tempat penyangga air mineral, hiasan rumah, gantungan kunci, nomor rumah dan lain-lain. Adanya limbah kayu tersebut, bernilai positif bagi pengrajin sangkar burung karena bahan baku kayu kering lebih mudah didapat dan efisien.

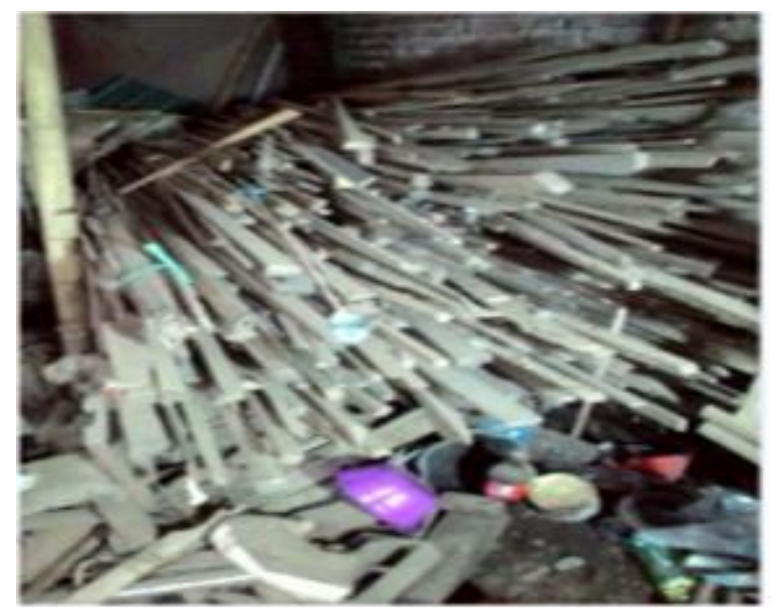

Gambar 1. Bahan baku kayu limbah

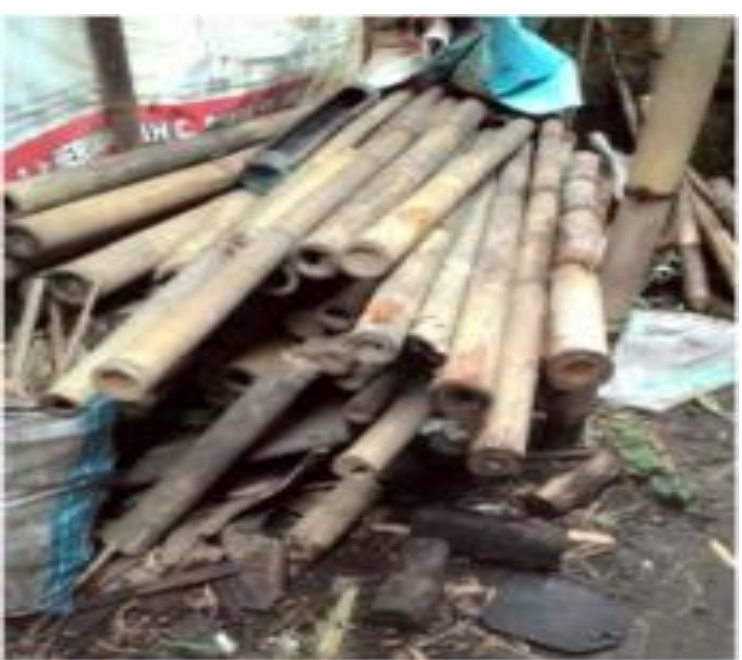

Gambar 2. Bahan baku bambu limbah

Terdapat dua mitra pengrajin sangkar burung di Desa Toyomarto Kecamatan singosari dalam kegiatan pengabdian masyarakat ini, yaitu : 1) Pengrajin sangkar burung "Karya Mandiri", milik Bapak Juanda yang beralamat di dukuh Bodean Putuk RT. 08, RW.04, Desa Toyomarto Singosari Kabupaten Malang. Industri sangkar burung ini ini telah beroperasi selama 16 tahun, dengan perkembangan yang stabil, tenaga kerja sebanyak 3 orang dan kapasitas produksi usaha ini mencapai 6 buah sangkar/hari. 2) Pengrajin sangkar burung "Lancar", milik Bapak Riyanto yang beralamat di dukuh Bodean Krajan RT. 04, RW.01, Desa Toyomarto Singosari Kabupaten Malang. Industri sangkar burung ini telah beroperasi selama 8 tahun, dengan perkembangan yang stabil, tenaga kerja sebanyak 2 orang dan kapasitas produksi usaha ini mencapai 4 buah sangkar/hari.

Sebagaimana yang telah disebutkan sebelumnya, bahan baku pembuatan kerajinan sangkar burung ini adalah adalah bambu dan kayu kering. Bahan baku bambu didapat dari pembelian tanaman bambu yang ada di pekarangan atau ladang di sekitar mitra, sedangkan, kayu kering didapat dari kayu limbah pembuatan meubel yang ada di desa Ardimulyo Singosari dalam bentuk batangan dengan ukuran 400 x $50 \mathrm{~cm}$. Kualitas kayu kering ini didasarkan kepada ukuran panjang, ketebalan, kepadatan serta tekstur (halus atau kasar) dari kayu tersebut. Harga kayu kaering dalam bentuk batangan dengan ukuran di atas berkisar antara Rp. $10.000,--20.000,-/ \mathrm{Kg}$.

Proses produksi pembuatan sangkar burung ini menggunakan beberapa peralatan manual dan penggerak listrik. Peralatan manual (murni tenaga manusia) berupa pisau potong, gergaji potong dan gergaji tangan. Sedangkan peralatan dengan penggerak listrik, berupa : bor tangan listrik, kompresor, mesin penghalus bambu, mesin penghalus jeruji bambu, alat press/penekan paku listrik, spray gun, gerinda tangan, dan lainnya. Proses pembuatan sangkar burung (Setyowibowo \& Mumpuni, 2016) dimulai dari pemotongan kayu menggunakan gergaji potong

kemudian menyerut kayu untuk meratakan, mengurangi ketebalan dan membuat permukaan kayu menjadi halus. Menyerut kayu merupakan dasar dari semua pekerjaan kayu, dan sangat menentukan untuk produk yang dihasilkan, karena bila kayu yang diserut tidak rata akan mempengaruhi tingkat akurasi proses berikutnya seperti penyambungan, membuat profil, membuat alur, dan lain-lain

Pengawetan jeruji sangkar diawali dengan mencapur boraks ukuran 100 gr dengan 1 liter air panas, dimasukkan ke dalam tong, selanjutnya jeruji sangkar direndam selama 1 minggu, kemudian dikeringkan dengan dijemur di panas matahari hingga benar-benar kering. Sedangkan proses pembuatan sangkar dilakukan melalui tahap pemotongan bahan kayu, digergaji sirkular, dibuat motif dengan gergaji jigsaw, dilubangi dengan dengan mesin bor, pemasangan jeruji sangkar dan yang terakhir adalah pengecatan dan penghalusan sesuai dengan model.

Gambar berikut adalah contoh proses pembuatan sangkar burung yang dilakukan di lokasi mitra. Proses pembuatan dimulai dari penyiapan bahan baku hingga finishing berupa pengecatan sangkar. 


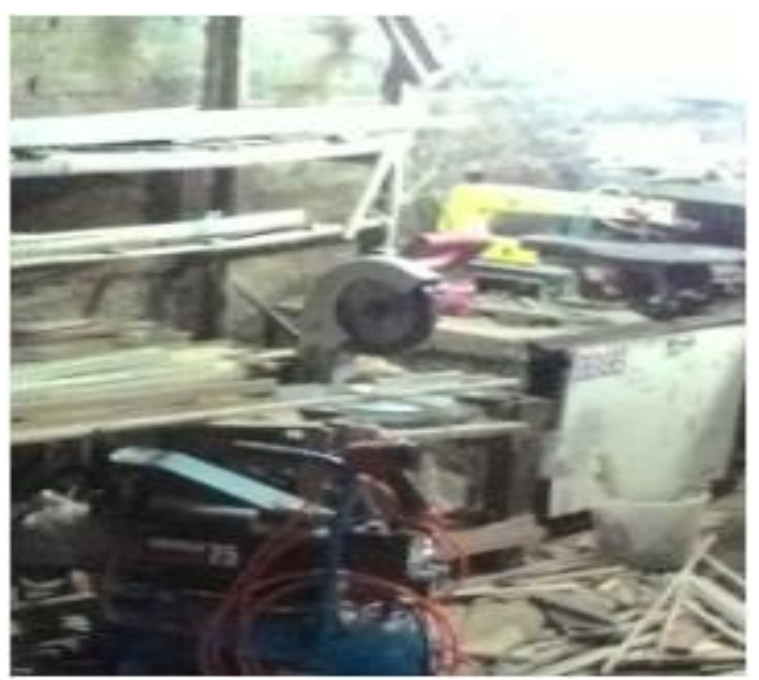

Gambar 3. Pemotongan bahan baku

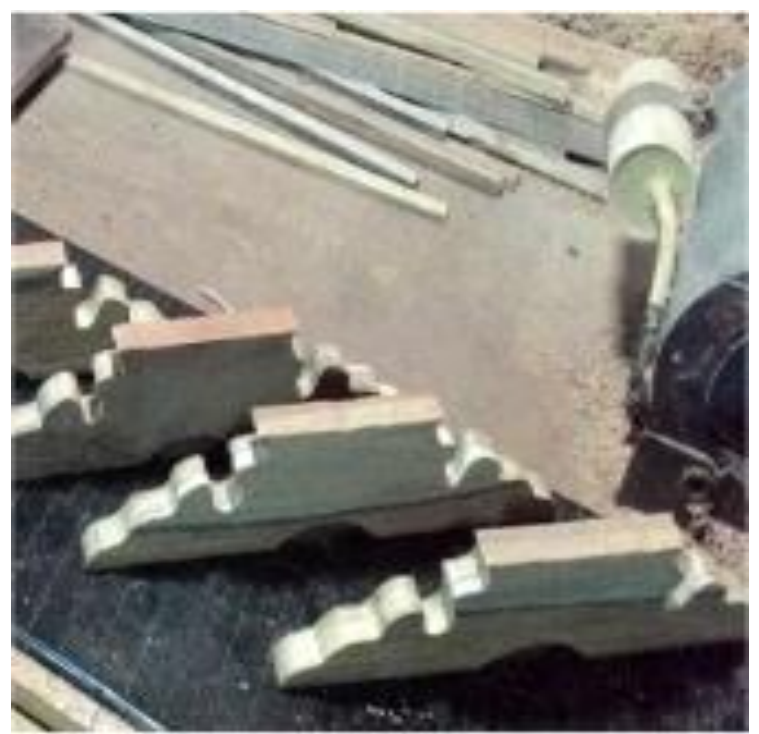

Gambar 5. Pembuatan mahkota sangkar

Permasalahan bidang produksi yang dapat diidentifikasi adalah terbatasnya peralatan proses produksi yang digunakan, disebabkan masih manualnya peralatan kerja pada proses pembelahan kayu, pemecahan bambu menjadi jeruji dan penyerutan jeruji agar menjadi halus. Pada tahap pembelahan kayu, dilakukan dengan menggunakan mesin potong kayu yang diangkat dengan tangan, akibatnya hasil pemotongan tidak rata dan tidak lurus. Cara tersebut juga membebani tukang potong sehingga cepat merasa kelelahan, akibatnya proses pembelahan kayu menjadi kurang cepat.

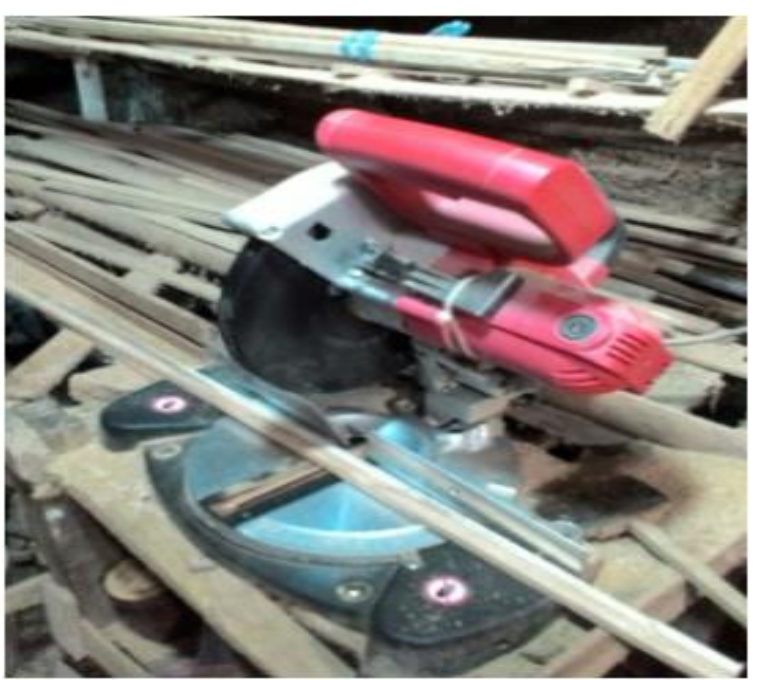

Gambar 4. Proses pembelahan kayu dengan cutting

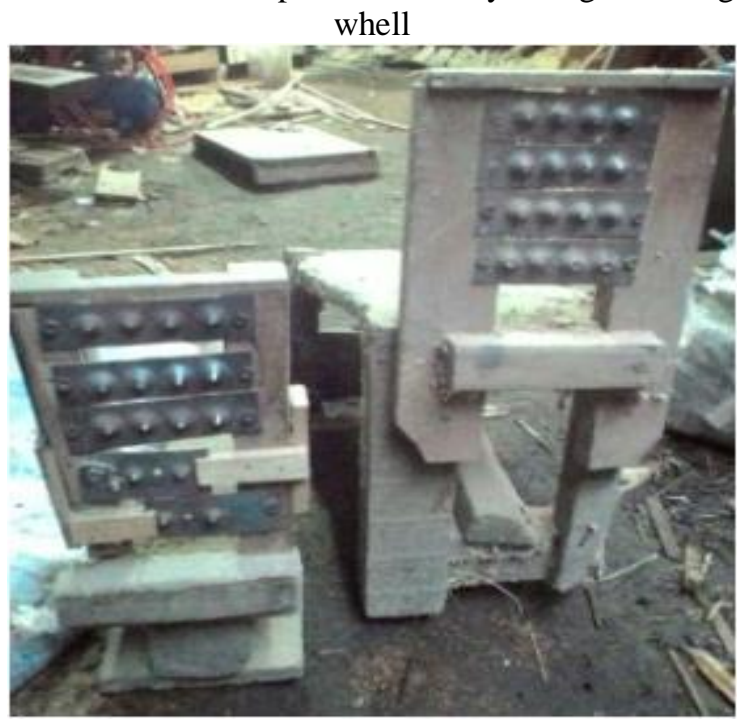

Gambar 6. Proses penghalusan jeruji bamboo

Pada proses pemecahan dan penghalusan bambu, peralatan yang digunakan masih sangat sederhana dan manual, sehingga waktu pengerjaannya menjadi lama dengan hasil yang kurang presisi dan kurang halus.

Setelah dilakukan diskusi antara pengusul dan mitra, maka prioritas masalah yang disepakati mitra untuk diselesaikan masalahnya adalah :

1) Peningkatan kemampuan alat pemotong dan pembelah kayu;

2) Perlunya alat serut dan penghalus bambu untuk jeruji sangkar yang tidak manual dan

3) Peningkatan kemampuan tenaga kerja dalam pengoperasian peralatan tersebut.

\section{METODE PELAKSANAAN}

Metode pelaksanaan yang dilakukan pada kegiatan ini berdasarkan pada luaran yang akan dihasilkan adalah :

1) Pembuatan alat pemotong dan pembelah kayu Metode pelaksanaan pada tahapan kegiatan ini sebagaimana dalam Danang (2011) adalah :

a. Merancang dimensi alat pemotong dan pembelah kayu

b. Mengidentifikasi kebutuhan komponen/bahan 
c. Mengadakan komponen yang dibutuhkan

d. Memotong kayu sesuai ukuran untuk dijadikan meja

e. Memotong besi sesuai ukuran untuk dijadikan sebagai kerangka meja

f. Merangkai komponen sesuai dengan rancangan hingga menjadi satu peralatan yang utuh

g. Melakukan ujicoba hingga dinyatakan layak

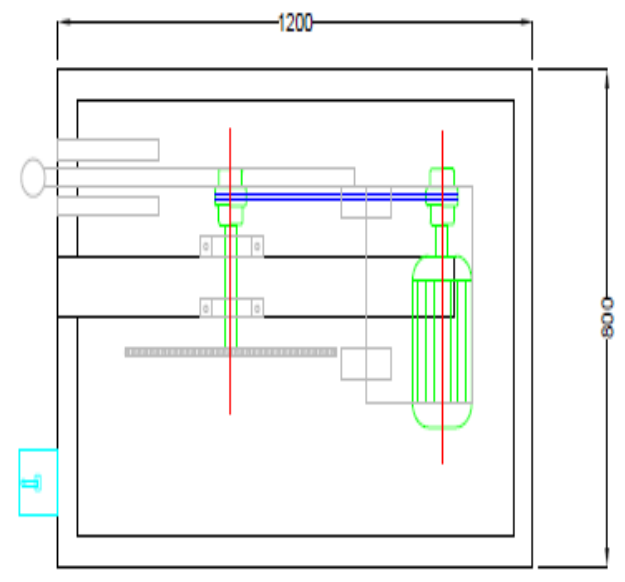

Gambar 7. Rancangan meja alat pemotong dan pembelah kayu tampak atas

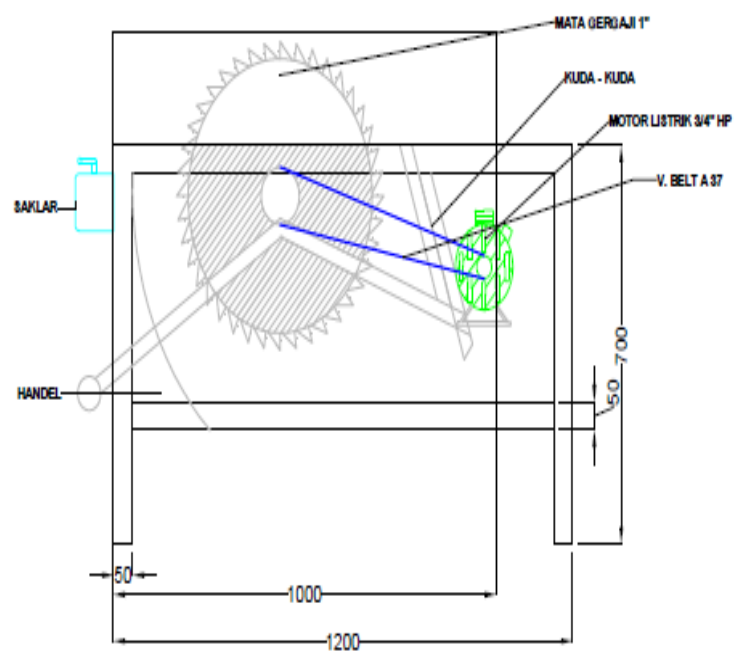

Gambar 8. Rancangan meja alat pemotong dan pembelah kayu tampak samping

2) Merancang dan membuat alat penyerut dan penghalus bambu

Metode pelaksanaan pada tahapan kegiatan ini adalah :

a. Merancang dimensi alat penyerut dan penghalus bambu

b. Mengidentifikasi kebutuhan komponen/bahan

c. Mengadakan komponen yang dibutuhkan

d. Memotong kayu sesuai ukuran untuk dijadikan meja

e. Memotong besi sesuai ukuran untuk dijadikan sebagai kerangka meja f. Merangkai komponen sesuai dengan rancangan hingga menjadi satu peralatan yang utuh

g. Melakukan ujicoba hingga dinyatakan layak

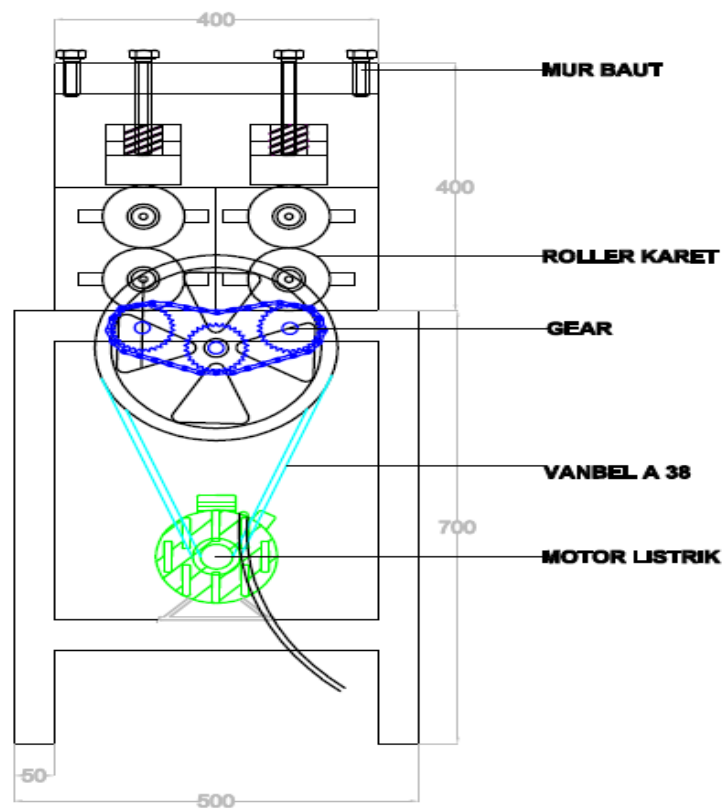

Gambar 9. Rancangan alat penyerut bambu tampak samping

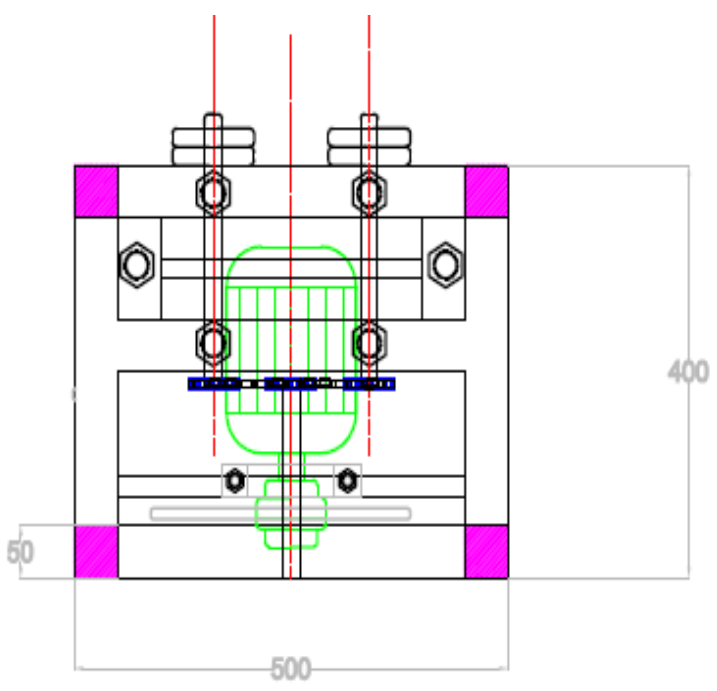

Gambar 10. Rancangan alat penyerut bambu tampak atas

3) Melatih dan mendampingi penggunaan peralatan yang telah dibuat

Metode pelaksanaan pada tahapan kegiatan ini adalah :

a. Membuat modul/materi pelatihan

b. Berkoordinasi dengan kedua mitra untuk menentukan waktu dan lokasi pelatihan

c. Melakukan pelatihan oleh pelaksana kegiatan dan tim pembantu

d. Melakukan pendampingan terhadap mitra hingga dianggap mampu

e. Melakukan evaluasi hasil pelatihan

f. Serah terima alat 
Dalam melaksanakan program ini dibutuhkan partisipasi mitra. Bentuk partisipasi mitra tersebut antara lain ádalah:

a. Berdiskusi dengan tim pelaksana dalam mencari solusi permasalahan dengan memberikan masukan-masukan dari pengalaman selama memproduksi sangkar burung.

b. Ikut memberikan masukan dalam mendesain alat.

c. Ikut serta dalam uji coba dan demonstrasi alat.

d. Menyiapkan tenaga kerja untuk dilatih dalam pemakaian dan pengoperasian alat

e. Kesiapan pemiliki usaha dan tenaga kerja dalam pelatihan penggunaan software pengelolaan arus kas dan media iklan

Evaluasi pelaksanaan program secara internal dilakukan oleh LPPM melalui melalui kunjungan lapang ke lokasi mitra sebagai bentuk pemantauan dan evaluasi untuk mengetahui pelaksanaan dan hasil kegiatan yang dilakukan. Keberlanjutan program dilakukan melalui tindak lanjut kegiatan Kuliah Pengabdian Masyarakat dan penguatan mitra untuk menjadi usaha binaan yang selama ini dilakukan oleh Pusat Pengembangan Kewirausahaan (P2K).

\section{HASIL DAN PEMBAHASAN}

Salah satu tujuan dari kegiatan pengabdian ini adalah untuk meningkatkan kapasitas produksi mitra melalui bantuan inovasi teknologi sebagimana kegiatan yang dilakukan oleh Faqih (Rofii, Hermawan, \& Tjahjono, 2016). Hasil yang dicapai pada kegiatan pengabdian ini, untuk bidang produksi adalah dihasilkannya alat alat pembelah kayu dan penyerut bambu, serta dampak produksi yang secara terukur dapat diuraikan sebagaimana berikut :

a) Pembuatan Alat Pemotong dan pembelah Kayu Alat ini mempunyai dua fungsi, yaitu untuk memotong kayu dan membelah kayu dengan spesifikasi sebagai berikut:

a) Bahan dari besi siku dan kayu

b) Meja kerja dengan dimensi Panjang $120 \mathrm{~cm}$, tinggi $80 \mathrm{~cm}$, lebar $70 \mathrm{~cm}$

c) Saklar on - off

d) Kabel

e) Pisau gergaji kayu dengan diameter 12 inci

f) Pulli besi 4 inci

g) Fan belt A 48

h) Motor listrik AC $3 \mathrm{Hp}$

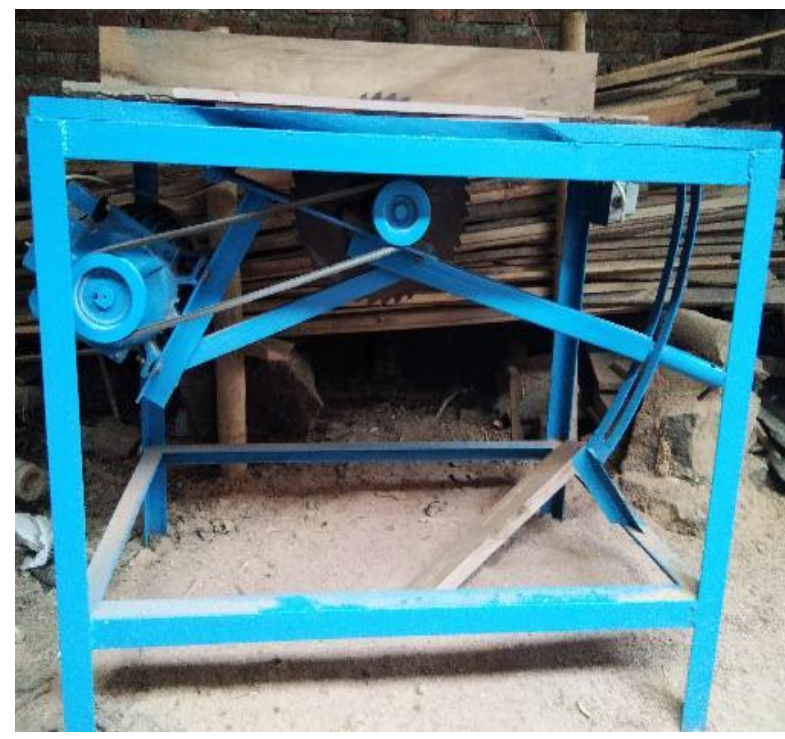

Gambar 11. Hasil lengkap pembuatan alat pemotong dan pembelah kayu

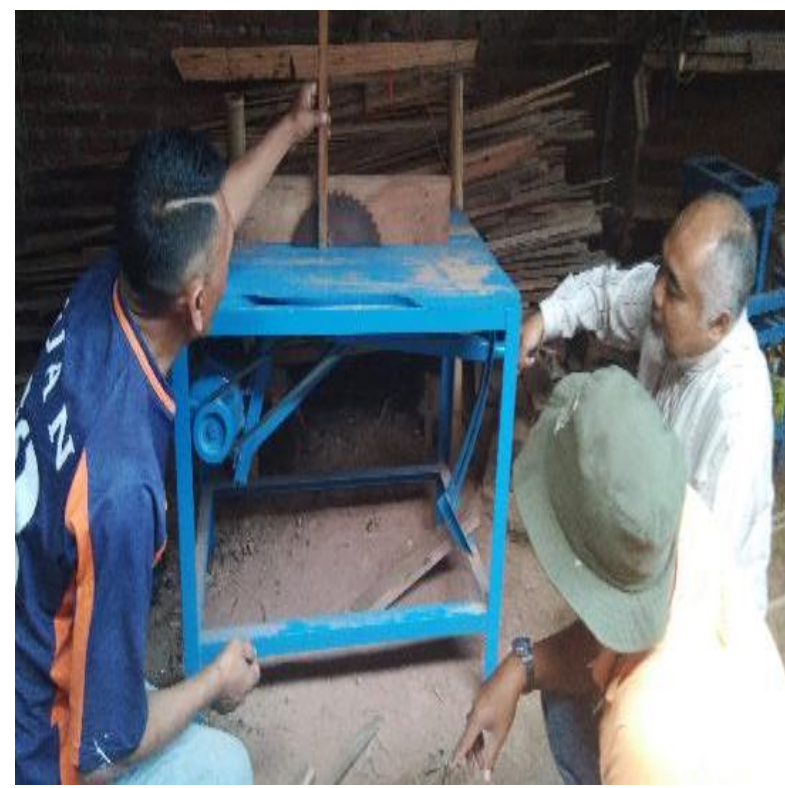

Gambar 12. Pengujian alat antara tim pelaksana dengan mitra

\section{b) Alat Penyerut Dan Penghalus Bambu Untuk Jeruji Sangkar}

Alat ini mempunyai dua fungsi, yaitu untuk menyerut dan menghaluskan bambu menjadi jeruji sangkar dengan spesifikasi alat sebagaimana berikut :
a) Bahan dari besi siku dan kayu
b) Panjang $80 \mathrm{~cm}$, tinggi $120 \mathrm{~cm}$, lebar $50 \mathrm{~cm}$
c) Fan belt A37
d) Roller karet 2 inci 4 buah
e) Rantai dan pulley
f) Pegas 1 inci
g) Kabel
h) Saklar on-off kab
i) Motor listrik AC 1,5 Hp
j) Per ulir 


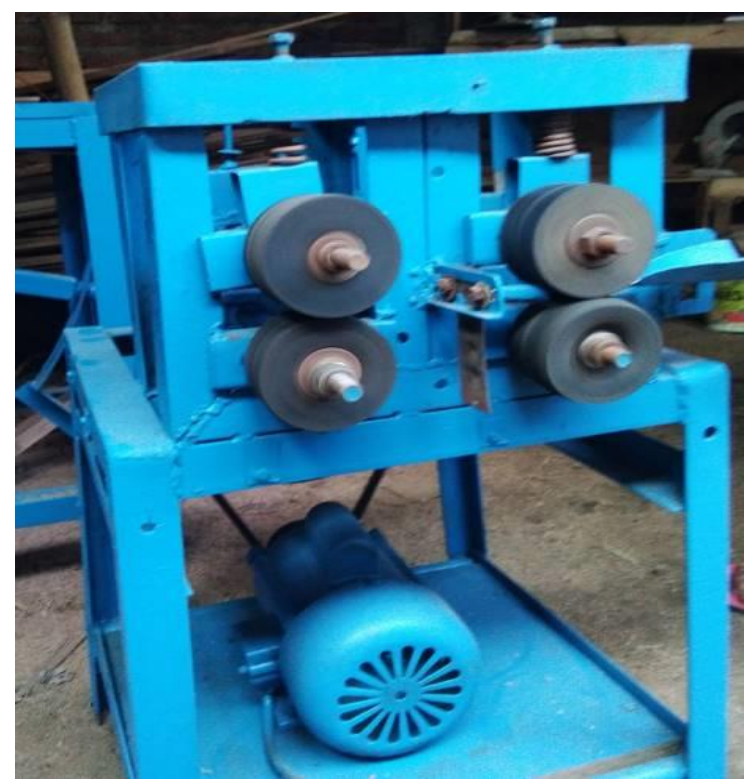

Gambar 13. Hasil pembuatan alat penyerut dan penghalus bambu

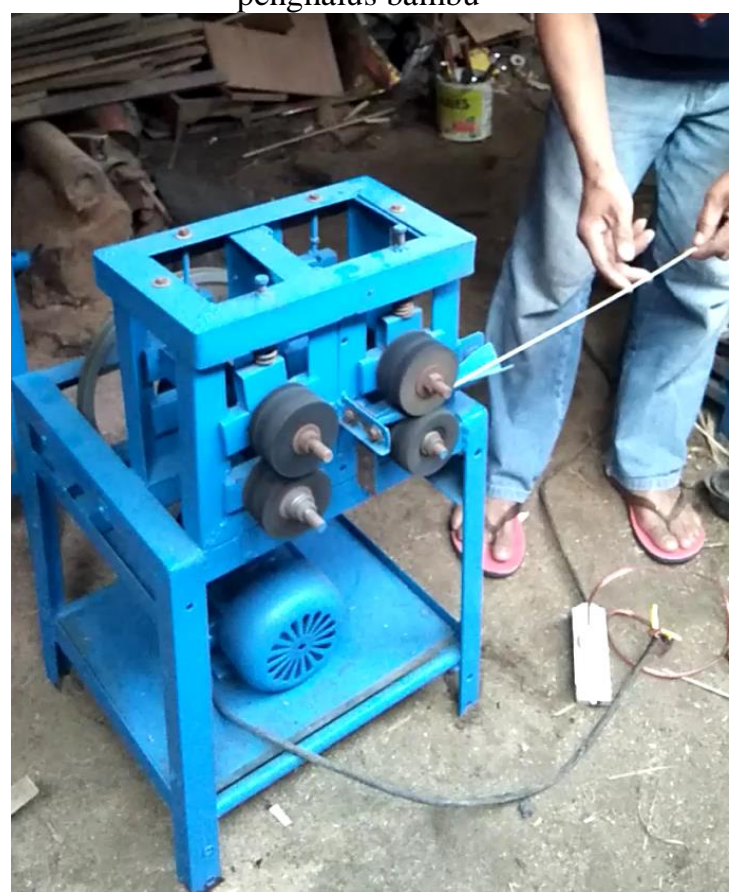

Gambar 4. Ujicoba alat penyerut dan penghalus kayu

\section{c) Dampak Pelaksanaan Hasil Kegiatan}

Berdasarkan hasil pengamatan dan wawancara langsung dengan mitra, alat yang telah dibuat, dapat digunakan dengan cara yang mudah serta dapat membantu meningkatkan produktifitas kegiatan mitra, sebagaimana terangkum dalam tabel berikut :
Tabel 1. Hasil pengukuran penggunaan alat pemotong dan pembelah kayu

\begin{tabular}{|c|c|}
\hline Kegiatan & Hasil yang dicapai \\
\hline $\begin{array}{l}\text { Perancangan dan } \\
\text { pembuatan alat } \\
\text { pemotong dan pembelah } \\
\text { kayu }\end{array}$ & $\begin{array}{l}\text { Alat pemotong dan } \\
\text { pembelah kayu }\end{array}$ \\
\hline \multicolumn{2}{|c|}{ Pengukuran } \\
\hline Sebelum kegiatan & Sesudah kegiatan \\
\hline $\begin{array}{l}\text { 1. Menggunakan alat } \\
\text { potong yang } \\
\text { diangkat dengan } \\
\text { tangan, kelemahan : } \\
\text { a) Membebani } \\
\text { tangan } \\
\text { b) Tidak lurus } \\
\text { c) Kurang halus }\end{array}$ & $\begin{array}{l}\text { 1. Menggunakan meja } \\
\text { kerja sehingga tidak } \\
\text { membebani tangan, } \\
\text { hasil pemotongan } \\
\text { lebih lurus dan } \\
\text { halus }\end{array}$ \\
\hline $\begin{array}{l}\text { 2. Tidak dapat } \\
\text { mengatur ketebalan } \\
\text { kayu yang akan } \\
\text { dibelah }\end{array}$ & $\begin{array}{l}\text { 2. Ketebalan kayu } \\
\text { yang akan dibelah } \\
\text { dapat diatur }\end{array}$ \\
\hline $\begin{array}{l}\text { 3. Jumlah kayu yang } \\
\text { dapat dipotong/ } \\
\text { dibelah } 25-30 \\
\text { potong kayu/jam } \\
\text { (tergantung kekuatan } \\
\text { tangan) }\end{array}$ & $\begin{array}{l}\text { 3. Jumlah kayu yang } \\
\text { dapat dipotong/ } \\
\text { dibelah } 60-70 \\
\text { potong kayu/jam } \\
\text { (lebih stabil) }\end{array}$ \\
\hline
\end{tabular}

Tabel 2. Hasil pengukuran penggunaan alat penyerut dan penghalus bambu

\begin{tabular}{|c|c|}
\hline Kegiatan & Hasil yang dicapai \\
\hline $\begin{array}{l}\text { Perancangan dan } \\
\text { Pembuatan alat penyerut } \\
\text { dan penghalus bambu }\end{array}$ & $\begin{array}{l}\text { Alat penyerut dan } \\
\text { penghalus bambu }\end{array}$ \\
\hline \multicolumn{2}{|c|}{ Pengukuran } \\
\hline Sebelum kegiatan & Sesudah kegiatan \\
\hline $\begin{array}{lr}\text { 1. } & \text { Sangat } \\
\text { kepada } & \text { bergantung } \\
\text { tangan } & \text { untuk } \\
\text { menyerut } & \text { dan } \\
\text { menghaluskan } & \\
\text { (manual) } & \end{array}$ & $\begin{array}{l}\text { 1. Tidak bergantung } \\
\text { kepada kekuatan } \\
\text { tangan, diganti } \\
\text { oleh mesin listrik } \\
\text { dan roller }\end{array}$ \\
\hline 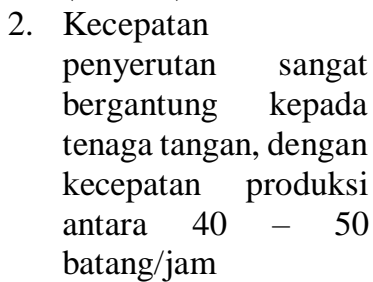 & $\begin{array}{l}\text { 2. Kecapatan } \\
\text { produksi mencapai } \\
150-170 \\
\text { batang/jam dengan } \\
\text { kecepatan hasil } \\
\text { yang stabil }\end{array}$ \\
\hline
\end{tabular}

Sebagaimana diperlihatkan oleh tabel 1, dapat diketahui dampak hasil pelaksanaan kegiatan yang terukur berdasarkan perbandingan kondisi sebelum dan sesudah kegiatan. Telah dihasilkan dua buah peralatan produksi, yaitu alat pembelah kayu dan penyerut bambu. Alat pembelah kayu yang sebelumnya berupa gergaji tangan telah dirubah menjadi meja kerja dengan gergaji yang digerakan dengan motor listrik, sehingga 
tidak membebani tangan dengan hasil lebih halus dan lurus, serta dapat diatur ketebalan kayu yang dibelah. Sedangkan alat yang kedua berupa alat penyerut bambu yang pada awalnya berupa alat manual dengan cara menarik bambu dengan tangan, sesudah kegiatan dihasilkan alat penyerut bambu yang digerakan dengan motor listrik, sehingga menjadi lebih ringan dan cepat, sehingga kecepatan produksi lebih meningkat dibanding sebelumnya.

\section{KESIMPULAN}

Berdasarkan tahapan kegiatan yang telah dilakukan dan hasil yang telah dicapai, dapat disimpulkan bahwa kegiatan pengabdian yang dilakukan mempunyai dampak pada peningkatan kapasitas produksi pembuatan sangkar burung pada mitra. Peningkatan ini disebabkan karena telah dihasilkannya dua buah alat produksi, berupa alat pembelah kayu dan peyerut bambu dengan penggerak motor listrik sehingga mempercepat proses produksi dan efisien dari sisi tenaga dan waktu pengerjaan. Dalam kegiatan ini belum diuraikan kegiatan dari aspek manajemen dan hasilnya. Hal ini akan dilakukan pada tahap selanjutnya sebagai bagian tak terpisahkan dari kegiatan pengabdian ini. Dalam proses kegiatan di bidang produksi ini, secara umum tidak ditemukan kendala yang besar, sehingga rangkaian kegiatan dapat dilakukan secara perencanaan.

\section{UCAPAN TERIMA KASIH}

Kegiatan pengabdian ini merupakan bagian dari kegiatan IPTEKS bagi Masyarakat yang dibiayai oleh Direktorat Riset dan Pengabdian Masyarakat Kemenristek Dikti. Ucapan terima kasih disampaikan penulis kepada Direktorat Riset dan Pengabdian Masyarakat Kemenristek Dikti yang telah membiayai kegiatan pengabdian ini dan kepada Lembaga Penelitian Masyarakat Universitas Widyagama Malang.

\section{DAFTAR PUSTAKA}

Danang, E. (2011). Proses Pembuatan Poros Gergaji Kayu Untuk Pembuatan Sangkar Burung. Skripsi. UNY.

Kicau, O. (2011, February 22). Penghobi Burung Semakin Banyak, Trafik Omkicau Terus Menanjak. diakses dari https://omkicau.com/2011/02/23/penghobiburung-semakin-banyak-trafik-omkicau-terusmenanjak/

Rofii, F., Hermawan, D., \& Tjahjono, N. (2016). Peningkatan Kapasitas Produksi Sandal Sepon Melalui Penggunaan Alat Perekat Lem Bertenaga Motor Listrik. Dinamika Dotcom, 7(2). 105-110

Setyowibowo, S., \& Mumpuni, I. D. (2016). Ibm Kerajinan Sangkar Burung Di Kelurahan Rejomulyo Kota Madiun. Jurnal Dedikasi, 13. 55-59 